\begin{tabular}{l|l} 
Dossier & BRICS AND MEDIATED \\
& $\begin{array}{l}\text { The proximity between Brazilian } \\
\text { news and telenovelas }\end{array}$ \\
SAMANTHA JOYCE \\
Saint Mary's College of California, United States of America \\
MOniCA MARTINEZ \\
Universidade de Sorocaba, São Paulo, Brazil
\end{tabular}

\author{
Copyright $\odot 2016$ \\ SBPjor / Associação \\ Brasileira de Pesquisa- \\ dores em Jornalismo \\ SAMANTHA JOYCE \\ MONICA MARTINEZ
}

\begin{abstract}
By analyzing the telenovela Caminho das Indias, broadcasted in 2009 and then again in 2015, this article discusses the concept of BRICS, more specifically of Brazil and India, and the question of soft power as a possibility of communicative and cultural influence which could contribute, through the diversity that is a staple of the block, to propose a counterpoint to the contemporary monoculture of worldviews. The argument used here is that audiovisual transnational narratives such as films (India) and television (Brazil) establish an important bridge between journalism and fiction. This is because they exercise, to some extent, an 'agenda-setting' role, in other words they are transformed newsworthy media, presenting the public with events and reflections on current issues. This paper discusses the relationship between the mediation between informationentertainment specifically in Brazilian telenovelas, analyzing the representation of the two countries through Brazilian author Gloria Perez's work.

Key words: Journalism. Brazil. India. Soap opera. Telenovela. Agenda-setting.
\end{abstract}

\title{
OS BRICS E AS NARRATIVAS MIDIÁTICAS: A proximidade entre as notícias e as telenovelas brasileiras
}

RESUMO - Por meio da análise da telenovela Caminho das Índias, exibida em 2009 e reexibida em 2015, este artigo discute o conceito dos BRICS, em particular de dois países, Brasil e Índia, e a questão do soft power enquanto uma possibilidade de influência comunicativa e cultural que poderia contribuir, por meio da diversidade que marca o bloco, para propor um contraponto à monocultura de visões de mundo na contemporaneidade. $\mathrm{O}$ argumento aqui empregado é o de que as narrativas audiovisuais ficcionais transnacionais cinematográficas (Índia) e televisivas (Brasil) estabelecem uma importante ponte entre o jornalismo e a ficção. Isso porque elas exercem, em alguma medida, papel de 'agenda-setting', isto é, transformam-se em veículos carreadores de notícias, levando ao público acontecimentos e reflexões sobre temas atuais. Neste artigo discutimos a relação entre a mediação informação-entretenimento especificamente nas telenovelas brasileiras, analisando a representação dos dois países por meio da obra da autora brasileira Gloria Perez.

Palavras-chave: Jornalismo. Brasil. Índia. Telenovela. Agenda-setting. 


\title{
LOS BRICS Y LAS NARRATIVAS MEDIÁTICAS:
}

la proximidad entre las noticias y las telenovelas brasileñas

\begin{abstract}
RESUMEN - Al analizar la telenovela Caminho das Indias, que se exhibió en 2009 y se exhibió de nuevo en 2015, este artículo analiza el concepto de BRICS, en particular los dos países, Brasil y la India, y la cuestión del poder blando como una posibilidad de influencia comunicativa y cultural lo cual podría contribuir, a través de la diversidad que marca el bloque, para proponer un contrapunto al monocultivo de visiones del mundo. El argumento utilizado es que las narrativas audiovisuales de ficción transnacionales en el cine (India) y de la televisión (Brasil) establecen un puente importante entre el periodismo y la ficción. Esto se debe a que ejercen, en cierta medida, el papel "agenda-setting", es decir, se convierten en vehículos portadores de noticia, lo que lleva a el público eventos y reflexiones sobre temas de actualidad. En este trabajo se analiza la relación entre la mediación informaciónentretenimiento específicamente en las telenovelas brasileñas, analizando la representación de los dos países a través del trabajo de la autora brasileña Gloria Pérez.

Palabras clave: Periodismo. Brasil. India. Telenovela. Agenda-setting.
\end{abstract}

\section{Introduction}

Through the analysis of the telenovela Caminho das Índias, originally broadcasted in 2009 and then again in 2015, this article examines the concept of BRICS, particularly of two countries, Brazil and India, as well as the issue of 'soft power' as a possibility as a communicative and cultural influence which could contribute, through the diversity that characterizes the group, to propose a counterpoint to the current monoculture of worldviews. We argue that the fictional audiovisual narratives in the case of the present article those of television, act under the agenda-setting optics - as proposed by theorists Maxell McCombs and Donald Shaw (MCCOMBS, 2009) - whereby the public is influenced by the issues highlighted by the media. Thus, we approach Brazilian telenovelas in general through their transnational character, and more specifically Caminho das índias, as follows: narrative wise, by taking into account the traditional melodramatic model, but also as a news medium, in other words, one that presents the public with current events and functions as an aggregator and curator of newsworthy elements. 


\section{A Brief history of BRICS}

The term BRIC was conceived by British economist Jim O'Neill, who is currently the head of Clobal Economy Research at the Goldman Sachs Financial Group in a study released by the organization on November 30, 2001 entitled Building better global economic BRICs (O'NEILL, 2001, p. 10). At the time, based on the GDP (Gross Domestic Product), the article hailed Brazil, Russia, India and China as "the biggest emerging market economies" (O'Neill, 2001 , p. 3). In the report, the economist pointed out - in relation to Brazil - the narrow social and stylistic ties with Europe and the US that characterize the country (O'Neill, 2001, p. 10). In 2011, at the request of China, South Africa joined the group and thus the group became BRICS. Other countries have tried to join the group, most recently Argentina, proposing their own inclusion in what would be the BRICSA. (CARNEIRO, 2015)'.

The potential for economic partnerships remains the tip of the iceberg group, as stated by the report The Strategy for BRICS Economic Partnership, published in the 2015 edition of the BRICS Summit, the group's meeting held in the Russian city of Ufa from July 26 to 29 .

\footnotetext{
BRICS is a dialogue and cooperation platform among Member States (Brazil, Russia, India, China and South Africa) which together account for $30 \%$ of global land, $43 \%$ of global population and $21 \%$ of the world's Gross Domestic Product (GDP), 17.3\% of global merchandise trade1, $12.7 \%$ of global commercial services 2 and $45 \%$ of world's Agriculture Production [...].The BRICS countries represent Asia, Africa, Europe and Latin America, which gives their cooperation a transcontinental dimension making it especially valuable and significant (BRICS, 2015).
}

Despite the different management models adopted by each country, "(...) all five countries, in their own ways, have embraced economies that are essentially capitalistic and, to various degrees, integrated into the US-dominated global economy, as demonstrated by the fact that the BRICS countries are in possession of 40 per cent of the global foreign exchange reserves - estimated to be $\$ 4.4$ trillion - and account for 21 per cent of the global GDP, which has increased threefold in the past 15 years (NORDENSTRENG; THUSSU, 2015, p. 3).

Apart from this economic perspective, diversity is what unites the five nations. The most visible difference, perhaps, is the political system: 
[...] Politically, the BRICS nations offer a range of political systems: with more than 800 million registered voters, India is the world's largest, most established and institutionalized democracy with a parliamentary system, while Brazil, after two decades of military dictatorship (1964-85), has emerged in the past quarter of a century as a robust democracy, based on a presidential system. South Africa is that continent's most successful democratic experiment, despite the grim legacy of apartheid. After years of socialism, as the system was called when the supreme power was held by the Communist Party, in the past three decades, Russia has moved towards a 'managed' democracy. China remains a one-party state, a system of government that distinguishes it from the other BRICS countries (NORDENSTRENG; THUSSU, 2015, p. 3).

In the Brazilian case it can be said that this "robust democratic system" is being put to the test, especially since 2013 , with varying protests that signal, in essence, two aspects. The first is the succession of political and economic character of crises affecting the world since 2008. This fits the current immigration crisis, leveraged by conflicts like Syria, ongoing since 2011 . This global instability, which is intensely and immediately affected by the media's technological developments, is directly related to the lack of confidence in political representative systems of each nation. According to James Curran, University of London:

\begin{abstract}
During the course of the twentieth century, the nation-state declined. The rise of unregulated international financial markets and transnational corporations able to relocate with relative ease, production to other countries, reduced the ability of national governments to manage their domestic economies. National governments were also under increasing pressure from the world economy to adopt market-friendly policies (such as low corporate taxation), irrespective of the wishes of their electorates. Governments of nations are still important in a wide area of everyday life (as highlighted in response to the economic crisis of 2008). But national government power and that of national electorates diminished as a consequence of deregulated globalization. This meant that the power of national electorates also declined. (CURRAN, 2015,).
\end{abstract}

The second aspect, which is related to the first, and very specific to the Brazilian political system today is the lack of a consolidated majority in Congress, which accommodates a myriad of around 30 different parties. The current government of Dilma Rousseff still faces lack of majority support from the population, which causes tensions, intense debates, and eventually protests, such as in 2015 . This governability crisis context is emphasized by 
the country's poor economic performance in 2015, evidenced by the difficulty of consensus on strategy, such as the adoption of budget adjustments, resulting, among other indicators, in the decline of GDP by $2.6 \%$ - the worst result since 1990 .

\section{BRICS as soft power: the cultural influence}

The fact that they are considered important global economic players seems to be the most visible and publicized tip of the BRICS iceberg. However, there are other impactful characteristics other than the economic one. One of the terms used to define this type of influence was coined in the 1980s by American political scientist Joseph Nye: soft power or 'poder brando' as opposed to hard power. In this context, soft power would represent the ability to influence the behavior or interests of others in ways that are not merely coercive or commercial (NYE, 2004), above all through communicative and cultural initiatives. Such notion is not a consensus. Nonetheless, its valid aspect is that a society is composed of multiple spheres, the economic one being important but not the only one.

There are ample challenges to the notion of globalization, including that the world would indeed be much less globalized than assumes the contemporary imagery (GHEMAWAT, 2008). It seems that the focus on globalization is indeed the fast interconnection between financial markets, which is possible due to technological advances advances that allow people around the world to monitor the news in virtually real time (STRAUBHAAR, 2015).

Brazilian theoretician Muniz Sodré names this phenomenon of rapid financial interconnectivity in the global scale - also noted by Curran - as the "financialization of the world":

Contemporary capitalism is both financial and mediatic: financialization and the media are the two faces of a coin called advanced society, the same one that has been receiving the prefix 'post' (post-industrialism, post-modern etc.). If prior communication and information, under the aegis of a productivist society, could be considered as extra expenses of capital, today we have a prominent place in the unity of the whole process, of financialization, in other words of wealth's new way of being. (SODRÉ, 2012, p. 16). 
Therefore this complexity has a direct relationship and is also reflected in the production and consumption of media, including transnational ones. Not coincidentally, Straubhaar emphasizes the phenomenon of hybridization of elements such as global television formats, that are however, made in each country with national, regional and local content (STRAUBHAAR, 2015, p. 91).

Thus, in the current context of globalization, would the BRICS have the potential for joint communication actions, or particular areas of expertise in which they could offer an alternative to American media production, with its ballast in the contemporary lingua franca, English? It is never too late to emphasize that diversity appears to be the greatest characteristic amongst BRICS, and not a monocultural worldview.

\section{Brazil and India: cultural influence through narratives}

Brazil and India are territorial giants: Brazil has the fifth largest territorial extension in the world, while India has the seventh. Both share political systems, of which India is the largest democracy in the world, adopting a parliamentary system, while the Brazilian is the presidential format. From this point on, we highlight the differences between the two nations. The first is the nature of their population: India has 1.295 billion people, and should surpass China in 2022, according to the United Nations (UN), if it maintains this pace of growth. As for Brazil, they have about a fifth of that total: 206.1 million (THE WORLD BANK, 2015). Secondly, income distribution: With a GDP (Gross Domestic Product) of US $\$ 2,067$ billion (2014), India is considered by the World Bank to have a lower level of average income. In that same year Brazil had a GDP of US \$2,246 billion, having its income level considered to be upper middle income by the same entity. Finally, the third difference we will highlight is linguistic: Brazil has only one official language, Portuguese; India on the other hand has Hindi, English and over 21 official languages, with over 400 languages and dialects spoken.

If there is unity between Brazil and India, it may be due to the fact that their populations know little and have a blurred vision, perhaps a mythical one, about one another. In a recent article, India's ambassador in Brazil, Sunil Lal, defined the issue: 
Brazilians do not properly understand India through local newspapers or television; nor do Indians learn a lot about Brazil in their media. [...] The general impression in India is that Brazilians dance samba with grace and style; that Rio is a big city; and that the mighty Amazon River flows through much of the country. They also know Pele. Few Indians know that the territory of Brazil is more than two and a half times that of India. Most Brazilians know Mahatma Gandhi and are aware that India's population exceeds one billion. That yoga came from India and the Taj Mahal is an Indian monument is also known. Tourists and businessmen and women have explored both countries, but not in large enough numbers. Our people need to be better connected and informed about each other. (LAL, 2015).

This perspective is reflected in the sharing of mediatic products, as claimed by International Communication professor Daya Kishan Thussu, from the Media Research Institute at the University of Westminster in London:

[...] Bollywood, the world's largest film factory, [...] is not at all visible in Latin America [...]. The fact that Brazil is the world's largest producer of telenovelas is also not very visible there. [...] (These are) huge markets. I imagine it's because this interaction is still at a very early stage. However, BRICS offer an interesting platform (MEDRADO, 2014).

In Communicating India's Soft Power: Buddha to Bollywood (2013), Thussu points out the role of the Indian diaspora, with 25 million people living abroad, especially in the US and the UK, which is important for the cultural products of the country, but also for the economy, by sending $\$ 10$ billion annually to India (THUSSU, 2013, p. 14). Likewise, the Brazilian diaspora influences the success of telenovelas. There is also their expansion to the Portuguese-speaking world, as in the case of Angola, Mozambique and Portugal, among others (SINCLAIR; STRAUBHAAR, 2013).

In Brazil, what happens is that the media systems are traditionally dominated by families, clans or groups, an inheritance from the Portuguese colonization, whose monarchy relied on powerful families to implement the process of occupation of the new lands (PAIVA; SODRÉ; CUSTÓDIO, 2014, p. 109). This ubiquitous interface, in which the boundaries are subtle, and are reflected in the Brazilian case, in the most traditional melodramatic style of the country. In addition to entertaining, the fictional narratives in some cases turn into news outlets, a medium that highlights current events to the public. This model is 
similar to other American non-journalistic television productions such as Daily Show ${ }^{2}$, in other words, a vehicle that functions as an aggregator of newsworthy elements that go beyond the limits of melodrama and permeate the pages of newspapers, in fact gaining prominence in the nightly newscasts.

This news-making characteristic (News producer) can be observed in Brazilian telenovelas for decades. As observed by Mattelart \& Mattelart (1990) in The Carnival of Images:

\begin{abstract}
In the press, discussion on the novela is not limited to specialized magazines that are of minor importance in Brazil. All press genres - daily, weekly, monthly, for all readerships - speak abundantly of telenovelas, including interviews with authors, actor, directors, producers and viewers, roundtables on themes, reviews by specialized journalists, academic analysis, humor, and gossip in the tittle-tattle press. On top of the copious press dossiers prepared by Globo and weekly program bulletins it publishes, most Brazilian magazines devote extensive articles to novellas that serve as veritable national events, continually reiterated (...) A history of the social impact of a telenovela could be written through its echo in the press. The sheer volume of articles on the novela is without echo in Europe (pp. 79-80) (MATTELART; MATTELART, 1990, p. 79-80)
\end{abstract}

According to Mattelart e Mattelart (1990), the content of Brazilian telenovelas is not relegated to the specialized media, but, has been historically highlighted in other media spaces. In this sense there traffic between the real and the fictional (MARTINEZ; CORREIA; PASSOS, 2015), as we will note bellow.

\title{
4 The proximity between brazilian journalism and dramaturgy
}

The close proximity between Brazilian news the telenovelas is more noticeable in the work of some writers. Such is the case of Gloria Perez, the author of Caminho das índias. Directed by Marcos Schechtman, this telenovela was broadcast for the first time between January 19 and September 11, 2009, in the 9 PM time slot in Rede Globo. Six years later, on July 27, 2015, the network reran the telenovela in the Vale a Pena Ver de Novo afternoon slot - a slot on the daily grid dedicated to reruns of previously successful telenovelas. Caminho das Índias was the first Brazilian telenovelas to win the biggest prize in world television - the International Emmy - in 2009.

Writer Gloria Perez, is used to having her narratives, as well 
as her personal story and tragedy permeate every section of the newspapers, as Bellos (2007) reminds us, in a piece written in the British The Telegraph,

\begin{abstract}
A decade and a half ago, as Brazilian president Fernando Collor de Mello was being impeached, the real scandal that gripped the nation was the murder of telenovela star Daniella Perez by her on-screen (telenovela) boyfriend, Guilherme de Pádua. The attack was spurred on by his real girlfriend's jealousy. In a further twist, the show's main screenwriter, Gloria Perez, was in fact Daniella's mother, and she continued the story for two months after her daughter's death, with Daniella appearing in flashbacks from alreadyshot footage. (BELLOS, 2007)
\end{abstract}

The incident helps us to illustrate the sometimesintense traffic between the news and the fictional narratives of telenovelas.

It is important to point out that traditionally telenovelas and, more specifically, Caminho das Índias, operate on a transnational space. Exported to nearly 90 countries when it aired for the first time in 2009, the program was also seen by the American public on the Telefutura channel, the American network of Spanish-language network Univisión. That brings up the fact that in addition to having to provide a successful product at home, the authors / writers also need to cultivate the overseas markets. So when it comes to the narrative between these two BRICS countries, Gloria Perez is both responding to these changes (transnational) as well as adapting its traditional strategy of using telenovelas to address political and social issues, in addition to those pertaining to multiculturalism, globalization, migration and diaspora, among others (STRAUBHAAR, 2012).

In order to understand the telenovela Caminho das Índias, and the journalistic discourses surrounding it as well as those surrounding Brazil and India, we must understand it in various ways: First, as a cultural/commercial production of the Globo Network, Brazil's largest media conglomerate. Secondly, we must take into account the fact that telenovelas and telenovela discourses are a complex site of mediations/representations. As Martín-Barbero (1997) reminds us, they are not merely melodramatic stories, but are also a site of struggle and contestation, retaining the traces of a popular culture that has resisted the direct imposition of dominant forms. Additionally, telenovelas are newsworthy and a key cultural product that 
brings the audience, or the country where it is being shown (daily) together. As Motter (2003) explains:

\begin{abstract}
The telenovela occupies a space as important or even more important than the TV news in the daily programming of the stations, since they satisfy the need to orient the viewer to their practical life, the daily episode of the serial fiction satisfies their curiosity regarding the unfolding of the narrative that is weaved daily (MOTTER, 2003, p. 22).
\end{abstract}

Furthermore, we must emphasize that it is in the telenovelas and in dramatic programs that the country see themselves and let themselves be seen (MARTíN-BARBERO; REY, 2001, p. 162).

\title{
5 Brazilian telenovelas historical background
}

On average, Brazilian telenovelas last about 150 episodes and have been the staple of TV programming for over six decades, being immediately followed by another telenovela. Audiences follow these stories - daily - for several months and they have in fact become an integral part of Brazilian culture early productions in Brazil started in the 1950s, and borrowed from a Cuban melodramatic template. As Joyce (2012) reminds us, these narratives, sometimes referred to as the Magadan Era, referring to Glória Magadan (1920-2001), the Cuban born writer. Such stories relied on narratives about exotic, distant lands and were sometimes based on classical novels. However, in the 1970s, Brazilian telenovelas took a turn and underwent a modernization process that encompassed language, styles, sets and narrative. Thus, Brazilian writers began incorporating real life socialpolitical and economic situations and events to the plots as a way to encourage the audiences' engagement and critical thinking.

It is noteworthy mentioning that even while Brazil was under a military dictatorship (1964 to 1985), telenovela authors, many of them left wing theater writers, were able to creatively bypass government censors to still address concrete problems of an increasingly urban society. As Fernandez (1997) states,

The expansion of the public, via the telenovela significantly decreased the number of turned off TV sets - this was another important element for the increased industrial investment in the most effective medium of broadcasting that the country had met (FERNANDES, 1997, p. 105). 
After the return to democracy in the late 1980s, themes that had been previously censored because they were considered inappropriate, such as those pertaining to politics, homosexuality, religion, racism and agrarian reform, began to appear more. As Calza states:

Rede Globo's implementation of Rede Globo, with all its technological apparatus, by far superior to everything that existed in the country, determined the way of making and consuming telenovelas. If previously we had imitated the European cultural tradition, now we export the product. And why? There was indeed "Brazilianization" of the genre. Our "modern" way to produce this kind of fiction was more close to the chronicle of daily life, opening itself up to discussions of the great moral, political, and religious taboos, such as homosexuality, drugs, virginity, themes impossible to be addressed in other more conservative cultures (CALZA, 1996, p. 8-9).

Since then, Brazilian telenovelas, especially TV Globo's productions, have been exported to many countries not only in Latin America but also in other continents such as China and Australia. It was the beginning of a growing movement. According to Bellos (2007), in 2005 TV Globo sold 44 thousand hours of its programming to 53 countries. The author states that Terra Nostra ("Our Land") based on the Italian migration to Brazil would have been sold to 87 countries and the TV Globo would charge up to $\$ 100,000$ per episode shown abroad, with a profit margin of $50 \%$. This means that there is an aggressive exploration of all the marketing possibilities for the genre, a practice known as merchandising. Today the narratives include prosocial content ranging from subplots to significant plots of the narrative. And Gloria Perez is known for including social merchandising in their productions.

A recent published report - Pesquisa Brasileira de Mídia 2015: hábitos de consumo de mídia pela população brasileira ("Brazilian media survey 2015: Media consumption habits of the Brazilian population") shows that television remains the predominant means of communication, and also reveals that Brazilian have spent more time in front of its screen. According to the survey, $95 \%$ of respondents said they watch TV, and $73 \%$ have the habit of watching every day. On average, Brazilians spend 4 hours and 31 daily minutes exposed to the TV set, Monday through Friday, and 4 hours and 14 minutes on the weekend these numbers 
are higher than those found in the same survey the previous year, which recorded 3 hours and 29 minutes and 3 hours and 32 minutes respectively (SECRETARIA DE COMUNICAÇÃO SOCIAL DA PRESIDÊNCIA DA REPÚBLICA, 2015, p. 7).

Another recent study, by the Observatório Ibero-Americano de Ficção Televisiva (Obitel) (“Ibero-American Observatory of Television Fiction - Obitel") a network which has brought together for the past ten years researchers from 12 countries $^{3}$, suggests that Internet use is not leading to the abandonment of the television screens. According to the coordinators of Obitel, "what we see is a series of transmidiations that highlight this technological migration phase experienced by many Latin American audiences in their relationship with 'old-new' media, with new and old screens" (LOPES; GÓMEZ, 2015 , p. 28). The "telenovela was again the main fictional format in the countries monitored by Obitel" (LOPES; GÓMEZ, 2015, p. 45), and amongst the top ten most viewed titles, seven are telenovelas (LOPES; GÓMEZ, 2015, p. 59).

It is in this context that the rerun of Caminho das Indias inserts itself, within the perspective of being a mediated representation of both countries, which we will demonstrate below.

\section{The mediatic representation of India steming from a brazilian telenovela}

In Caminho das Índias, Gloria Perez is both responding to those changes as well as adapting her traditional strategy of using telenovelas to engage in prosocial, economic and political relations, in this case between Brazil and India.

In addition to its social/critical component, another key aspect of Brazilian telenovelas, which distinguish them from other productions of this kind, is the systematic inclusion of social merchandising (JOYCE, 2012; LA PASTINA; PATHEL; SCHIAVO, 2004), a variation of the Entertainment-Education approach developed by Miguel Sabido based on psychological theories of Albert Bandura (JOYCE, 2012; LA PASTINA; PATHEL; SCHIAVO, 2004).

The inclusion of prosocial storylines in Brazilian telenovelas can be traced as far back as the 1970s, with issues such as the importance of literacy (LA PASTINA; PATHEL; SCHIAVO, 2004). While in the beginning these insertions were 
the product of a writer's personal agenda, starting in the 1990s, the Globo network began to provide an infrastructure to these campaigns that was backed up by research, in order to maximize the impact of such campaigns (JOYCE, 2012; LA PASTINA; PATHEL; SCHIAVO, 2004).

Gloria Perez has a long and successful career in TV Globo, which started in 1979. She has written telenovelas and miniseries and is notorious for including social merchandising to her plots as well as an element of multiculturalism and transnationality. In addition to Caminho das índias, the author also included both of those aspects to O Clone ("The Clone" - 2001-2002), with which this trend started and also became one of the most successful Brazilian telenovelas. O Clone was partly set in an 'other' land, in this case, Morocco. Here the writer introduced issues relating to Islamic customs and culture, as well as drug and alcohol abuse and addiction, in addition to ethical questions of cloning, especially human cloning (MALCHER, 2010). Her next telenovela, America (2005), was set in Brazil and in Miami and discussed social and transnational issues, such as homosexuality, online pedophilia, and problems faced by the visually impaired, as well as issues pertaining to the US-Mexico border, such as the illegal immigration of Brazilians who use that route. Caminho das índias (2009) was followed by Salve Jorge ("Hail Jorge", 2012-2013), which followed similar pattern, with Gloria Perez incorporating a social and political issue into a mediated discourse and transnational mediated space: the narrative moves between Brazil and Turkey and addresses, among other things, the trafficking and enslavement of women.

Keeping in line with the social merchandising/multicultural perspective, in 2009, Gloria Perez presented audiences in Brazil and abroad with Caminho das índias, a tremendous success chosen as the best telenovela in the world at the 37 th International Emmy Awards. Some of the social problems discussed in this program were psychiatric problems such as Schizophrenia. The condition was addressed through a class perspective as two characters suffered from the disease: a rich young man, Tarso (actor Bruno Gagliasso) and a poor one, Ademir (actor Sidney Santiago). Following the tradition introduced first in Explode Coração/Exploding Hearts and later in O Clone, real life patients told audiences about their real-life experiences pertaining to that 
topic in a series of journalistic style interviews (DUARTE, 2005; MEDINA, 1990).

In Caminho das Índias, actors, who were Brazilian, spoke Portuguese, except for some Hindu words and expressions here and there. The driving plot is a love story between the two main couples in the narrative, Bahuan / Maya (Indians) and Raj / Duda (Indian / Brazilian). In addition to the traditional obstacles of melodramas, such as class division, this story also has the problem of castes. Bahuan is described to viewers as an untouchable, a Dalit, or lower class, although he holds a degree from a US university in computer science - another simplistic representation of expatriate Indians. His position as dalit makes his relationship with Maya, described as a vaishya, a merchant's daughter, impossible. This was also the case of Raj, another vaishya with Duda, a Brazilian/foreigner. The plot thus represents a version of India imagined by Gloria Perez, and inspired by Bollywood productions, with its bright colors, elaborate costumes, and music and dance sequences. To create a sense of truthfulness and verisimilitude many scenes were shot in picturesque locations such as Jaipur. However, this was a reinterpretation of India, sanitized and organized, very different from the creative chaos that is a part of the everyday life of that northern city in the country.

In the Brazilian mediatic representation there is a unifying language in India, Hindi. In regards to work, Gloria Perez also used stereotypical representations, as both Bahuan and Raj are associated with technology, and the protagonist, Maya, works in the early episodes of the narrative in a call center. Raj's family business is the sale of fabrics and silk. Religion was also addressed simplistically and homogeneously, with Hinduism - the predominant religion in the country - presented as the only option, with no references to Islam or Buddhism, for example.

However, even this simplified representation of the country increased the interest in the Indian culture and traditions during the time of the broadcast of the telenovela. The Indian ambassador to Brazil at the time, Prakash Bellur, revealed that all of a sudden he began to receive a flood of emails inquiring about India and its customs. He claims that during the time that the telenovela aired, he experienced the strangest and strongest manifestation of soft power he had seen in his long and varied 
career (PRAKASH, 2009). He added that although "The whole story is told in Portuguese with a liberal sprinkling of phrases like theek hai, chalo, bhagwan ke liye, arre baba being spoken by the Indian characters to make them sound authentic, such representation was not necessarily bad:

\begin{abstract}
What gives color and flavor to the soap is the staple of curiosities about India: Caste, arranged marriage, elaborate weddings, exotic rituals and the many-headed Gods. All these are in abundance and hence the e-mails that we are getting in the embassy If most Brazilians think that we all live in mini-marble palaces, wear exquisite embroidered silks, and are constantly dancing happily to Bollywood tunes, I should not be complaining, I told myself. Since then we have just enjoyed the attention to India that we now see in our lives in this country... 'What do you think about the novella?' my Brazilian friends frequently ask me. 'Is it authentic?' I do not want to get into a debate on the accuracy of the depiction in this fiction. This novella has made India so popular, that no ambassador can ask for a better platform or a more propitious climate for projecting the real India,' I answer truthfully. 'And I am planning our revenge by thinking of an Indian soap on Brazil with all its standard images: sensuous Samba dancers, sensational bikini models, and the famed football stars playing a cricket match on Mumbai beach,' (PRAKASH, 2009).
\end{abstract}

With a great sense of humor, Parkash sensed that these representations would not have been any more in depth had the narrative been Indian about Brazil, which possibly would contain sexy samba dancers, sculptural women with bikinis and soccer stars playing cricket, the favorite sport of the country, on a beach in Mumbai, the epicenter of Bollywood. In this sense, both ambassadors in 2009 and the current one, agree with the statement that these two BRICS members would gain valuable insight if only they knew each other better. (LAL, 2015; PRAKASH, 2009).

\title{
Final considerations
}

This article assumes that there is a close link between the news and fictional narratives. This assumption is examined in the context of the BRICS (Brazil, Russia, India, China and South Africa) as not just an acronym that refers to the economic aspect, but as an influential block that can contribute globally as far as their culture and above all, diversity - after all, the eating habits, history, 
development, and political systems are very different in each of the five nations that form the block. Data indicates this large block as the representative of $30 \%$ of the soil, $43 \%$ of the population, $21 \%$ of the gross domestic product (GDP), $17.3 \%$ of in trade, $12.7 \%$ of services and $45 \%$ of the world's agricultural production.

In this context, narratives are seen as the greatest agents of communicational and cultural influence. As an example of narrative as an instrument of soft power, this article proposes a reflection on the contemporary fictional traditions of India and Brazil, as Bollywood is the world's largest film industry and Brazilian telenovelas are the great Brazilian export. Both are influential in their own domestic markets, but also beyond the respective boundaries, present in diasporas and hence between speakers of respective public official languages of each of the two countries. This study highlights both the fascination between the two peoples and the need for bridges and more effective dialogue between these two great cultures, since there is little knowledge of Brazil from the perspective of Indians and vice versa.

Our main argument is that this mediation occurs as a ubiquitous relationship in which the boundaries between the real - and the resulting coverage and journalistic discourses - and the fictional are subtle, if not convergent. This paper proposes to address the Brazilian telenovela, more specifically Caminho das Índias, since in addition to entertaining, the fictional narratives in some cases turn into news vehicle, a way to take to the public events and reflections on current issues. In this sense, it is a model similar to other non-US news television productions such as the Daily Show, in other words, a vehicle that functions as an aggregator of newsworthy elements that go beyond the limits of the melodrama and permeate the pages of newspapers, coming to prominence in the nightly newscasts.

This close proximity between the news and the Brazilian telenovelas is more noticeable in some writer's works, such as Gloria Perez. Based on this fact, the article examined Caminho das Índias, which represented the two communities (Brazil and India) in a mediatic way. Originally broadcasted in 2009 , the telenovela is on currently seen as a rerun (2015-present) in the Vale a Pena Ver de Novo ("This is Worth Watching Again") slot. According to TV Globo's perspective this was a successful telenovela, and the first to 
win an International Emmy in 2009. According to the Ambassador of India in Brazil at the time, albeit simplified, the soap opera triggered a deep interest in Indian culture, with repercussions in the Brazilian social matrix.

\section{Notes}

1 In 10/052015, the United States and 11 other nations with opening to the Pacific Ocean Japan, Canada, Chile, Australia, Brunei, Malaysia, New Zealand, Mexico, Peru, Singapore and Vietnam) announced the formation of another block, the Treaty of Trans-Pacific Association (TPP), immediately considered a historic free trade agreement since, together, these countries currently make up $40 \%$ of the world economy.

2 Daily Show is an American news television program which satirizes U.S. politics aired since July 22, 1996. Its actual host is comedian Trevor Noah.

3 The 12 countries gathered by Obitel network are Argentina, Brazil, Chile, Colombia, Ecuador, Spain, United States, Mexico, Peru, Portugal, Uruguay and Venezuela.

\section{References}

BELLOS, A. Telenovelas : the story so far. Retrieved July 1, 2015, from The Telegraph: The Telegraph, 2007.

BRICS. THE STRATEGY FOR BRICS ECONOMIC PARTNERSHIP. Ufa: [s.n.]. Avaliable at: <http://en.brics2015.ru/documents/>.

CALZA, R. O que é telenovela. São Paulo: Brasiliense, 1996.

CARNEIRO, M. Cristina defende "Bricsa", com a Argentina, em evento com Lula. Folha de S.Paulo, 2015.

CURRAN, J. Media and Democracy13o. Encontro Nacional de Pesquisadores em Jornalismo. Anais...Mato Grosso do Sul: SBPJor, 2015.

DUARTE, J. Entrevista em profundidade. In: DUARTE, J.; BARROS, A. (Eds.). 
Métodos e técnicas de pesquisa em Comunicação. São Paulo: Atlas, 2005. p. 62-83.

FERNANDES, I. Memória da telenovela brasileira. 4. ed. São Paulo: Brasiliense, 1997.

GHEMAWAT, P. Redefiniendo la globalización: la importância de las diferencias em um mundo globalizado. Espanã: Planeta, 2008.

HAMBURGER, E. O Brasil antenado: a sociedade da novela. Rio de Janeiro: Jorge Zahar, 2005.

JOYCE, S. N. Brazilian Telenovelas and the Myth of Racial Democracy. Maryland: Lexington Books, 2012.

LA PASTINA, A.; PATHEL, D. S.; SCHIAVO, M. Social Merchandizing in Brazilian Telenovelas. In: SINGHAL, A. et al. (Eds.). EntertainmentEducation and Social Change. New Jersey: Lawrence Eribaum Associates, Inc, 2004. p. 261-277.

LAL, S. Brasil brilhante, Índia incrível. Folha de S.Paulo, p. A3, 28 ago. 2015.

LOPES, M. I. V. DE; GÓMEZ, G. O. Relações de gênero na ficção televisiva: anuário Obitel 2015. Porto Alegre: Sulina, 2015.

MALCHER, M. A. Teledramaturgia : agente estratégico na construção da tv aberta brasileira. São Paulo: Intercom, 2010.

MARTIN-BARBERO, J. Dos meios as mediações: comunicação, cultura e hegemonia. 2. ed. Rio de Janeiro: Editora UFRJ, 2003.

MARTÍN-BARBERO, J.; REY, G. Os exercícios do ver: hegemonia audiovisual e ficção televisiva. São Paulo: Senac São Paulo, 2001.

MARTINEZ, M.; CORREIA, E. L.; PASSOS, M. Y. R. Entre fato e ficção: personagens compostos versus fraude em jornalismo. Estudos em Jornalismo e Mídia, v. 12, n. 2, p. 238-250, 2015.

MATTELART, M.; MATTELART, A. The carnival of images: Brazilian television fiction. New York: Bergin \& Garvey, 1990.

MCCOMBS, M. A teoria da agenda: a mídia e a opinião pública. Petrópolis, RJ: Vozes, 2009.

MEDINA, C. Entrevista: o diálogo possível. 2. ed. São Paulo: Ática, 1990.

MEDRADO, A. O Ocidente, o "resto" do mundo e a internacionalização dos Estudos de Mídia - "Chíndia", BRICS e soft power. Matrizes, v. 8, n. 2, p. 137-149, 2014. 
MOTTER, M. DE L. Ficção e realidade: a construção do cotidiano na telenovela. Comunicaçã ed. São Paulo: Alexa Cultural, 2003.

NORDENSTRENG, K.; THUSSU, D. K. Mapping BRICS media. 1. ed. London: Routledge, 2015.

NYE, J. S. Soft Power: the means to success in world politics. New York: Public Affairs, 2004.

O'NEILL, J. Building better global economic BRICs. Global Economics, n. 66, p. $15,2001$.

PAIVA, R.; SODRÉ, M.; CUSTÓDIO, L. Brazil: patrimonialism and media democratization. In: NORDESTRENG, KAARLE; THUSSU, D. K. (Ed.). . Mapping Brics Media. 1. ed. London: Routledge, 2014. p. 109-124.

PASTINA, A. LA. Selling political integrity: telenovelas, intertextuality, and local elections in rural Brazil. Journal of Broadcasting and Electronic Media, v. 48, p. 302-325, 2004.

PRAKASH, S. The Indian soap opera that's taken Brazil by storm. Rediff Movies, 25 jun. 2009.

SECRETARIA DE COMUNICAÇÃO SOCIAL DA PRESIDÊNCIA DA REPÚBLICA. Pesquisa Brasileira de Mídia 201 5: hábitos de consumo de mídia pela população brasileira. Brasília: [s.n.]. Avaliable at: <http://www. secom.gov.br/atuacao/pesquisa/lista-de-pesquisas-quantitativase-qualitativas-de-contratos-atuais/pesquisa-brasileira-de-midiapbm-2015.pdf>.

SINCLAIR, J.; STRAUBHAAR, J. Latin America Television Industries. 1. ed. London: British Film Institute, 2013.

SODRÉ, M. Comunicação: um campo em apuros teóricos. Matrizes, v. 5, n. 2, p. 11-27, 2012.

STRAUBHAAR, J. Telenovelas in Brazil: from travelling scripts to a genre and proto-format both national and transnational. In: OREN, T.; SHAHAF, S. (Eds.). Global television formats: Understanding television across borders. New York: Routledge, 2012. p. 148-177.

STRAUBHAAR, J. BRICS as emerging cultural and media powers. In: THUSSU, D. K.; NORDENSTRENG, K. (Eds.). Mapping Brics Media. 1. ed. London: Routledge, 2015. p. 272.

THE WORLD BANK. World Development Indicators. Avaliable at: <http://data.worldbank.org/>. Acesso em: 29 set. 2015.

THUSSU, D. K. Communicating India's Soft Power: Buddha to

Bollywood. 1. ed. Houndmills: Palgrave Macmillan, 2013. 
Samantha Nogueira Joyce has a PhD in Media Studies from the University of lowa and a Masters Degree in Radio and Broadcasting from San Francisco State University. She is an Assistant Professor of Communication at Saint Mary's College of California. Email: samanthanjoyce@yahoo.com.

Monica Martinez has a PhD in Communication (University of São Paulo), a postdoctoral by Umesp, and has conducted postdoctoral research at the University of Texas in Austin. She is full professor on the Communication and Culture Graduate Program at Uniso and is colider at Contemporary Media Narratives Network (SBPJor). Email: martinez.monica@uol.com.br. 